\title{
Review: Sintesis Dan Karakterisasi Nanopartikel Emas (AuNP) Serta Konjugasi AuNP Dengan DNA Dalam Aplikasi Biosensor Elektrokimia

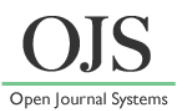

\author{
Egista Istioka Fazrin, Annisa Ilma Naviardianti, Santhy Wyantuti, \\ Shabarni Gaffar, Yeni Wahyuni Hartati* \\ Department Kimia, FMIPA, Universitas Padjadjaran \\ *Email: yeni.w.hartati@unpad.ac.id
}

DOI: https://doi.org/10.33369/pendipa.4.2.21-39

\begin{abstract}
The use of gold nanoparticles (AuNP) is an appropriate one in the development of biosensors because it has a unique, strong adsorption, high biocompatibility, and large surface area. AuNPs can be synthesized by various methods with the same synthesis principle by reducing $A u^{3+}$ to Au. This review explains the various methods of AuNP synthesis and their characteristics, the interaction of AuNP with biomolecules including DNA, and the application of AuNP-DNA bioconjugates in biosensors. Several applications of AuNP-DNA bioconjugates as electrochemical biosensors in the past two years are proposed in this review.
\end{abstract}

Keywords: AuNP, AuNP-DNA bioconjugate, electrochemical biosensor.

[ABSTRAK] Penggunaan nanopartikel emas (AuNP) merupakan suatu pendekatan yang tepat dalam pengembangan biosensor karena memiliki karakteristik unik, adsorpsi yang kuat, biokompatibilitas tinggi, dan luas permukaan yang besar. Dalam perkembangannya AuNP dapat disintesis dengan berbagai macam metode dengan prinsip sintesis yang sama yaitu dengan mereduksi ion logam $\mathrm{Au}^{3+}$ menjadi $\mathrm{Au}$. Ulasan ini menjelaskan berbagai metode sintesis AuNP dan karakterisasinya, mekanisme interaksi AuNP dengan biomolekul termasuk DNA, dan aplikasi biokonjugat AuNP-DNA dalam biosensor. Beberapa aplikasi biokonjugat AuNP-DNA sebagai biosensor elektrokimia dalam dua tahun terakhir ini dilaporkan dalam ulasan ini.

Kata kunci: AuNP, biokonjugat AuNP-DNA, biosensor elektrokimia.

\section{PENDAHULUAN}

Penggunaan nanopartikel merupakan salah satu pendekatan yang tepat dalam pengembangan biosensor. Nanopartikel adalah suatu partikel logam maupun polimer dalam ukuran skala 1-100 nm. Fungsi nanopartikel dalam biosensor adalah untuk meningkatkan amobilisasi biomolekul, katalis reaksi elektrokimia, pelabelan molekul dan meningkatkan transfer elektron (Pingarrón et al., 2008). Terdapat beberapa jenis nanopartikel logam mulia yang digunakan dalam aplikasi biosensor namun AuNP memiliki fitur yang cocok dalam meningkatkan sensitifitas dan selektifitas dari biosensor karena memiliki biokompatibilitas, sifat optik, elektronik, produksi dan modifikasinya yang relatif sederhana (Biju, 2014).

Karena memiliki banyak kelebihan, penggunaan AuNP dari tahun ke tahun semakin meningkat. Hal ini membuat metode sintesis AuNP pun beragam dan terus mengalami modifikasi untuk menghasilkan suatu AuNP yang stabil. Untuk mengetahui suatu partikel telah berhasil disintesis atau tidak maka dilakukan karakterisasi. Karakterisasi AuNP bertujuan untuk mengetahui distribusi ukuran partikel dan morfologinya dimana dalam nanopartikel kedua parameter tersebut sangatlah penting dalam karakterisasi nanopartikel. AuNP dapat dikarakterisasi dengan menggunakan Spektroskopi UV-VIS, Transmission Electron 
Microscopy (TEM), Scanning Electron Microscopy (SEM).

Kemampuan AuNP dalam berinteraksi dengan sel telah mendorong para peneliti untuk mengkonjugasikan berbagai senyawa dan makromolekul biologis dalam upaya meningkatkan fungsionalitas karena AuNP berpotensi dapat menstabilkan dan melindungi DNA, Aptamer, RNA, dan konjugat lain. Konjugasi AuNP dengan makromolekul biologis disebut dengan Biokonjugat (Delong et al., 2010). Konjugasi DNA dengan AuNP memiliki peran penting dalam biosensing karena memiliki sifat optik yang sangat baik dari AuNP dan fungsi pengenalan molekul DNA. Dalam biosensor berbasis elektrokimia, penambahan biokonjugat merupakan suatu upaya yang tepat karena dapat meningkatkan sensitivitas, batas deteksi yang rendah serta uji deteksinya berlangsung cepat dan sederhana (Emami et al., 2014). Pada review ini dijelaskan mengenai penggunaan AuNP yang dikonjugasikan dengan DNA, sintesis dan karaterisasi AuNP, dan aplikasinya terhadap biosensor elektrokimia dalam dua tahun terakhir.

\section{SINTESIS DAN KARAKTERISASI AUNP}

AuNP merupakan material berukuran kecil, tetapi ketersediannya dalam jumlah besar menjadi penting karena banyak diperlukan untuk aplikasi komersial dan industri (Baer, 2013). Keadaan oksidasi emas meliputi $\mathrm{Au}^{+1}$ (aurous), $\mathrm{Au}^{+3}$ (auric/aurat), dan yang tidak teroksidasi adalah $\mathrm{Au}^{0} . \mathrm{Au}^{0}$ adalah kondisi akhir yang diinginkan untuk nanopartikel. Jadi, langkah utama yang melibatkan sintesis AuNP adalah mereduksi $\mathrm{Au}^{+1}$ atau $\mathrm{Au}^{+3}$ menjadi $\mathrm{Au}^{0}$ dengan menambahkan donor elektron (agen reduksi) dalam reaksi. Prekursor pilihan bagi sebagian besar peneliti adalah asam kloroaurat, HAuCl4 dengan emas dalam tingkat oksidasi $\mathrm{Au}^{+3}$ (Baer, 2013).

Menurut Zeng et al sintesis AuNP pertama kali dilakukan oleh Turkevich pada tahun 1951 dimana metode tersebut paling umum digunakan. Pada metode ini, Pendekatan umum dalam pembuatan larutan emas koloid adalah sintesis partikel dari garam emas $\left(\mathrm{HAuCl}_{4}\right)$ menggunakan zat pereduksi. Penggunaan natrium sitrat menghasilkan larutan koloid yang memiliki stabilitas yang sangat baik dan ukuran partikel dengan diameter $20 \mathrm{~nm}$. Dalam metode ini, larutan $\mathrm{HAuCl}_{4}$ dipanaskan kemudian ditambahkan trisodium sitrat dihidrat dengan cepat di bawah pengadukan yang kuat. Setelah beberapa menit, warna larutan berubah dari kuning muda menjadi merah anggur. Dalam teknik ini, ion sitrat berfungsi sebagai agen penstabil dan pereduksi dan menghasilkan AuNP yang memiliki ukuran sekitar $22 \mathrm{~nm}$ (Hu et al., 2006, Turkevich et al., 1951). Beberapa penelitian menggunakan metode Turkevich untuk mensintesis AuNP diantaranya: Kimling et al mengatakan konsentrasi sitrat yang tinggi lebih cepat menstabilkan AuNP dengan ukuran yang lebih kecil, sementara konsentrasi sitrat yang kecil akan menyebabkan agregasi partikelpartikel kecil menjadi partikel yang lebih besar. Babaei et al menggunakan metode "inversed Turkevich" dalam penelitiannya. Menurutnya, metode tersebut dapat digunakan sebagai metode sederhana untuk mensintesis AuNP ukuran besar hingga $51 \mathrm{~nm}$ dengan monodispersitas tinggi dalam satu langkah. Zhang et al menyiapkan AuNP berair, dengan menambahkan $4 \mathrm{~mL}$ natrium sitrat $1 \%$ menjadi $100 \mathrm{~mL}$ larutan $\mathrm{HAuCl}_{4}$ mendidih $0,01 \%$. Campuran diaduk sampai warna anggur merah tua diperoleh, menunjukkan pembentukan suspensi AuNP dengan ukuran $10 \mathrm{~nm}$.

Brust-Schiffrin pada tahun 1994 mengembangkan metode Turkevich yang selanjutnya dinamakan dengan metode BrustSchiffrin. Metode ini memiliki pendekatan yang mudah untuk sintesis AuNP agar stabil secara termal dengan ukuran yang dapat dikontrol dan kemampuan disperse yang rendah. Dalam teknik ini, $\mathrm{AuCl}_{4}^{-}$dipindahkan ke fase toluena dari larutan berair menggunakan tetraoctylammonium bromide (TOAB) sebagai agen transfer fase, dan direduksi oleh $\mathrm{NaBH}_{4}$, dengan adanya dodecanethiol. Penambahan zat pereduksi menyebabkan perubahan warna fase organik, dari jingga ke coklat tua yang menunjukkan AuNPs telah terbentuk (Hu et al., 2006, Turkevich et al., 1951).

Shon et al (2009) menggunakan metode Brust-Schiff rin dalam penelitiannya yaitu $0,39 \mathrm{~g}$ $(1,0 \mathrm{mM}) \mathrm{HAuCl} 4$ dilarutkan dalam $40 \mathrm{~mL}$ H2O nanopure dan $1,09 \mathrm{~g}(2,0 \mathrm{mM})$ TOAB dalam 160 $\mathrm{mL}$ toluena ditambahkan ke dalam labu reaksi. 
Campuran reaksi diaduk selama 10 menit sebelum penambahan $0,38 \mathrm{~g}(10 \mathrm{mM}) \mathrm{NaBH} 4$. Solusi yang dihasilkan mengandung TOABAuNPs dengan 3,4 nm menunjukkan warna ungu / merah yang kuat. Kim et al menambahkan 120 mL larutan HAuCl4 (1,6 g, 4,0 mM) ke TOAB $(5,5 \mathrm{~g}, 10,0 \mathrm{mM})$ yang dilarutkan dalam toluena $(240 \mathrm{~mL})$ dan diaduk selama 2 menit. Chlorobenzenemethanethiol $(0,32 \mathrm{~g}, 2,0 \mathrm{mM})$ dilarutkan dalam toluena ditambahkan diikuti oleh natrium borohidrida $(0,8 \mathrm{~g})$ dalam air (50 $\mathrm{mL}$ ). Larutan campuran diaduk selama 3 jam, fase toluena dipisahkan dan volume larutan dikurangi menjadi $30 \mathrm{~mL}$. Produk kotor diendapkan menjadi metanol $(500 \mathrm{~mL})$, dan kemudian disaring dan dicuci dengan metanol $(400 \mathrm{~mL})$. Ukuran partikel akhir adalah antara 3 dan $4 \mathrm{~nm}$.

Sintesis AuNP secara elektrokimia pertama kali dipelajari oleh Reetz et al pada tahun 1994 (Hu et al., 2006, Turkevich et al., 1951). Dalam penelitiannya menunjukkan bahwa skala nano ukuran partikel logam transisi dapat diatur secara elektrokimia menggunakan garam tetra alkil amonium sebagai stabilisator kluster logam dalam media yang tidak mengandung air. AuNP pada permukaan karbon multi-dinding nanotube dengan elektroda karbon kaca dapat disiapkan menggunakan teknik sintesis elektrokimia (Song et al., 2013). AuNP dibuat secara elektrokimia menggunakan sel dua elektroda sederhana, dengan oksidasi anoda dan reduksi katoda (Herizchi et al., 2016).

Metode yang umum juga untuk sintesis AuNP adalah metode kimia. Pada metode ini, AuNP dapat disintesis melalui proses reduksi kimia dengan menggunakan agen pereduksi seperti borohidrida, aminoboran, formaldehida, hidrazin, hidroksilamin, poliol, asam sitrat dan oksalat, gula, hidrogen peroksida, karbon monoksida, tes sulfi, hidrogen, asetilena. Selain dengan agen pereduksi dapat juga dilakukan stabilisasi menggunakan suatu zat, misalnya trisodium sitrat dihidrat, ligan belerang (khususnya tiolat), ligan fosfor, ligan berbasis oksigen, ligan berbasis nitrogen (termasuk senyawa heterosiklik), dendrimer, polimer dan surfaktan (khususnya, cetyltrimethylammonium bromide) (CTAB). Untuk menghindari agregasi partikel, beberapa jenis zat penstabil biasanya ditambahkan (Zhao et al., 2013) (Herizchi et al., 2016). Secara garis besar sintesis nanopartikel dilakukan dengan metode top-down (fisika) dan metode bottom-up (kimia). Pada metode topdown padatan logam dibuat menjadi ukuran nano secara mekanik, sedangkan dengan metode bottom-up, logam dilarutkan dengan agen pereduksi dan penstabil untuk merubahnya ke dalam bentuk nano (Khairurrijal dan Mikrajuddin, 2009). Tetapi, metode-metode tersebut memiliki banyak masalah yang mencakup penggunaan pelarut yang beracun, limbah yang berbahaya dan konsumsi energi yang tinggi (Thakkar et al, 2011). Metode green synthesis yang menggunakan ekstrak tanaman sebagai reduktan dan zat penstabil untuk sintesis nanopartikel logam telah banyak diminati di bidang penelitian dalam 3 tahun belakangan. Pendekatan sintesis hijau memberikan kemajuan dibandingkan metode lain karena hemat biaya, sederhana, ramah lingkungan dan dapat diproduksi ulang. Prinsip metode green synthesis nanopartikel logam ialah memanfaatkan tumbuhan atau mikroorganisme sebagai agen pereduksi. Mikroorganisme yang digunakan seperti bakteri, jamur dan khamir. Hal ini didasarkan pada kemampuan tumbuhan dalam menyerap ion logam dari lingkungan, lebih aman dan ramah lingkungan dibandingkan dengan penggunaan bahan-bahan kimia anorganik (Handayani, 2011). Jenis tumbuhan yang mengandung bahan reduktor ini cukup melimpah dan mudah didapatkan di wilayah Indonesia. penambahan volume bioreduktor yang semakin besar menyebabkan semakin banyak pula ion $\mathrm{Au}^{3+}$ yang tereduksi menjadi $\mathrm{Au}^{\circ}$. Hal tersebut disebabkan oleh tumbukan partikel antara bioreduktor dan ion $\mathrm{Au}^{3+}$ yang semakin sering terjadi. Penambahan volume bioreduktor yang semakin besar menyebabkan absorbansi maksimum yang dihasilkan semakin besar pula. Hal tersebut membuktikan bahwa semakin banyak AuNP yang dihasilkan (Sovawi, 2016). Beberapa penelitian sintesis AuNP dengan metode green synthesis dalam dua tahun terakhir disajikan dalam Tabel 1. 
Tabel 1. Beberapa metode green synthesis AuNP dalam dua tahun terakhir

\begin{tabular}{|c|c|c|c|c|}
\hline No & Nama Tumbuhan & Agen pereduksi & Ukuran & Referensi \\
\hline 1. & $\begin{array}{l}\text { Sargassum } \\
\text { crassifolium }\end{array}$ & Ekstrak & $25-200 \mathrm{~nm}$ & (Ouano et al., 2018) \\
\hline 2. & Artemisia dracunculus & Ekstrak & $35-50 \mathrm{~nm}$ & $\begin{array}{l}\text { (Wacławek et al., } \\
\text { 2018) }\end{array}$ \\
\hline 3. & Diospyros kaki & Ekstrak daun & $45-65 \mathrm{~nm}$ & (Oyar et al., 2018) \\
\hline 4. & Annona squamosa & Ekstrak kulit & $2-11 \mathrm{~nm}$ & (Gangapuram et al., 2018) \\
\hline 5. & Acacia Senegal & Gum Arabic & $22 \mathrm{~nm}$ & $\begin{array}{l}\text { (Eskandari-Nojehdehi et al., } \\
\text { 2018) }\end{array}$ \\
\hline 6. & $\begin{array}{l}\text { Elaeis guineensis } \\
\text { (kelapa sawit) }\end{array}$ & Ekstrak daun & $35-75 \mathrm{~nm}$ & (Ahmad et al., 2018) \\
\hline 7. & $\begin{array}{l}\text { Dalbergia } \\
\text { coromandeliana }\end{array}$ & $\begin{array}{l}4 \text { 'methylenedioxyis } \\
\text { oflavone } \\
\text { (Dalspinin) }\end{array}$ & $\sim 10.5 \mathrm{~nm}$ & $\begin{array}{l}\text { (Umamaheswari et al., } \\
\text { 2018) }\end{array}$ \\
\hline 8. & Jatropha curcas & $\begin{array}{l}\text { Ekstrak de-oiled } \\
\text { jatropha waste } \\
\text { (DJW) }\end{array}$ & $\sim 14 \mathrm{~nm}$ & (Kanchi et al., 2018) \\
\hline 9. & Indigofera tinctorial & Ekstark daun & $9-26 \mathrm{~nm}$ & (Vijayan et al., 2018) \\
\hline 10. & Thyme & Ekstrak & $35 \mathrm{~nm}$ & (Hamelian et al., 2018) \\
\hline 11. & Nerium oleander & ekstrak kulit batang & $20-40 \mathrm{~nm}$ & (Chandan Barai et al., 2018) \\
\hline 12. & Cannabis sativa & ekstrak air batang & $12-20 \mathrm{~nm}$ & (Singh et al., 2019) \\
\hline 13. & Alga merah & $\begin{array}{l}\text { Carrageenan } \\
\text { oligosaccharide } \\
\text { (CAO) }\end{array}$ & $8-35 \mathrm{~nm}$ & (Chen et al., 2018) \\
\hline 14. & Backhousia citriodora & Ekstrak daun & $8.40 \mathrm{~nm}$ & (Khandanlou et al., 2018) \\
\hline 15. & Ziziphus ziziphus & Ekstrak daun & $30-50 \mathrm{~nm}$ & (Aljabali et al., 2018) \\
\hline 16. & Limbah sayuran & $\begin{array}{l}\text { Ekstrak limbah } \\
\text { sayuran }\end{array}$ & $7-60 \mathrm{~nm}$ & (Mythili et al., 2018) \\
\hline 17. & Pistacia Atlantica & $\begin{array}{l}\text { Ekstrak daun dan } \\
\text { buah }\end{array}$ & $50-60 \mathrm{~nm}$ & (Hamelian et al., 2018) \\
\hline 18. & Coffea arabica & Ekstrak benih & $16-64 \mathrm{~nm}$ & (Bogireddy et al., 2018) \\
\hline 19. & Punica granatum & Ekstrak kulit & $5,4-13 \mathrm{~nm}$ & (Biao et al., 2018) \\
\hline 20. & Agaricus bisporus & Ekstrak & $25 \mathrm{~nm}$ & $\begin{array}{l}\text { (Eskandari-Nojehdehi et al., } \\
\text { 2018) }\end{array}$ \\
\hline 21. & Pterocarpus Santalinus & Ekstrak kulit & $13-26 \mathrm{~nm}$ & $\begin{array}{l}\text { (Keshavamurthy et al., } \\
\text { 2018) }\end{array}$ \\
\hline 22. & Juglans regia & Ekstrak buah & $3-19 \mathrm{~nm}$ & (Izadiyan et al., 2018) \\
\hline 23. & Medicago sativa & Ekstrak benih & $66 \mathrm{~nm}$ & (Keshavarzi et al., 2018) \\
\hline 24. & Origanum vulgare & Ekstrak daun & $\sim 40 \mathrm{~nm}$ & (Benedec et al., 2018) \\
\hline 25. & $\begin{array}{l}\text { Rhynchotechum } \\
\text { ellipticum }\end{array}$ & Ekstrak daun & $8,3 \mathrm{~nm}$ & (Chaudhuri et al., 2018) \\
\hline 26. & Salvia officinalis & Asam rosmarinat & $30.46 \mathrm{~nm}$ & (Lim \& Park, 2017) \\
\hline 27. & S. nodiflora & Ekstrak daun & $18,91 \mathrm{~nm}$ & (Vijayan et al., 2018) \\
\hline
\end{tabular}




\begin{tabular}{|c|c|c|c|}
\hline 28. Palm oil fronds (POFs) & $\begin{array}{l}\text { Ekstrak Palm oil } \\
\text { fronds (POFs) }\end{array}$ & $32-79 \mathrm{~nm}$ & (Usman et al., 2018) \\
\hline 29. Muntingia calabura & Ekstrak buah & $27 \mathrm{~nm}$ & ( Kumar et al., 2018) \\
\hline 30. Padina tetrastromatica & Ekstrak & $11,4 \mathrm{~nm}$ & (Princy \& Gopinath, 2018) \\
\hline 31. Olax nana & Ekstrak daun & $\sim 47 \mathrm{~nm}$ & (Ovais et al., 2018) \\
\hline 32. Alpinia nigra & Ekstrak daun & $21.52 \mathrm{~nm}$ & (Baruah et al., 2018) \\
\hline 33. Ricinus communis & Ekstrak daun & $2.5-10,5 \mathrm{~nm}$ & (Abdelghany et al., 2019) \\
\hline 34. Croton bonplandianum & Ekstrak daun & $\sim 79 \mathrm{~nm}$ & (Vijay Kumar et al., 2018) \\
\hline 35. Arctium lappa & Ekstrak akar & $24,7 \mathrm{~nm}$ & (Nguyen et al., 2018) \\
\hline 36. Punica Granatum & Ekstrak buah & $40-100 \mathrm{~nm}$ & (Gubitosa et al., 2018) \\
\hline 37. Mangifera indica & Ekstrak benih & $46,8 \mathrm{~nm}$ & (Vimalraj et al., 2018) \\
\hline $\begin{array}{l}\text { 38. Alternanthera } \\
\text { bettzickiana }\end{array}$ & Ekstrak daun & $80-120 \mathrm{~nm}$ & (Nagalingam et al., 2018) \\
\hline 39. Syzygium cumini & Ekstrak benih & $20,52 \mathrm{~nm}$ & (Kadiyala et al., 2018) \\
\hline 40. Prosopis farcta & Ekstrak daun & $25 \mathrm{~nm}$ & (Miri et al., 2018) \\
\hline 41. Dillenia indica & Ekstrak daun & $5 \mathrm{~nm}-50 \mathrm{~nm}$ & (Huang et al., 2019) \\
\hline $\begin{array}{l}\text { Kulit kacang } \\
\text { Macadamia mentah }\end{array}$ & limbah kulit kacang & $50 \mathrm{~nm}-2 \mu \mathrm{m}$ & (Dang et al., 2019) \\
\hline 43. Hibiscus sabdariffa & Ekstrak daun & $7 \mathrm{~nm}$ & (Mohd Taib et al., 2019) \\
\hline 44. Citrus sinensis & Ekstrak buah & $1.75 \mathrm{~nm}$ & (Yang et al., 2019) \\
\hline 45. $\begin{array}{l}\text { Anacardium } \\
\text { occidentale }\end{array}$ & Ekstrak daun & $10 \mathrm{~nm}-60 \mathrm{~nm}$ & (Sunderam et al., 2018) \\
\hline $\begin{array}{l}\text { 46. Croton Caudatus } \\
\text { Geisel }\end{array}$ & Ekstrak daun & $20 \mathrm{~nm}-50 \mathrm{~nm}$. & (Vijaya Kumar et al., 2019) \\
\hline 47. Bauhinia purpurea & Ekstrak daun & $50 \mathrm{~nm}$ & (Vijayan et al., 2019) \\
\hline 48. Fusarium oxysporum & $\begin{array}{l}\text { Fusarium } \\
\text { oxysporum }\end{array}$ & $25-30 \mathrm{~nm}$ & (Naimi-Shamel et al.,2019) \\
\hline 49. $\begin{array}{l}\text { Sansevieria } \\
\text { roxburghiana }\end{array}$ & Ekstak daun & $2 \mathrm{~nm}$ & (Kumar et al., 2019) \\
\hline 50. Solanum nigrum & Ekstak daun & $9-26.5 \mathrm{~nm}$ & (Asnag et al., 2019) \\
\hline 51. Ricinus communis & Ekstak daun & $2.5-10.5 \mathrm{~nm}$ & (Asnag et al., 2019) \\
\hline 52. Morus nigra & Ekstak daun & $16-51.5 \mathrm{~nm}$ & (Asnag et al., 2019) \\
\hline 53. Dunaliella salina & Ekstrak air & $22.4 \mathrm{~nm}$ & (Singh et al., 2019) \\
\hline 54. Tribulus terrestris & Ekstrak buah & $7-55 \mathrm{~nm}$ & (Gopinath et al., 2019) \\
\hline 55. Vitex negundo & Ekstak daun & $20-70 \mathrm{~nm}$ & (Veena et al., 2019) \\
\hline 56. Buah Naga & Ekstrak buah & $10-20 \mathrm{~nm}$ & (Divakaran et al., 2019) \\
\hline
\end{tabular}


57. kelapa sawit

58. ganggang merah

59. Scutellaria barbata

60. Solanum melongena

61. Coleus aromaticus

62. Eucalyptus globulus

63. Rosmarinus officinalis

64. Abies spectabilis

65. Cornus Mas

66. escin, glikosida

67. Lonicera japonica

68. Gracilaria verrucose

69. Lignosus rhinocerotis

70. alcea rosea

71. Agrimonia Pilosa

72. Juniperus communis $\mathrm{L}$.

73. Alternanthera Sessilis

74. Madu

75. Cressa cretica

76. Garcinia mangostana $L$

77. Parmelia sulcate

78. encalyptus globulus

79. Lycium chinense
Ekstrak daun

Agarosa

tanaman Scutellaria barbata matang

ekstrak kulit

Ekstrak daun

Ekstrak daun

R. officinalis

Ekstrak tanaman

dengan polifenol dari ekstrak Cornus Mas

Escin

Ekstrak bunga

Ekstrak daun

Ekstrak daun

Ekstrak daun

Ekstrak bagian udara A. Pilosa

Ekstrak daun

Ekstrak daun

larutan madu yang

dimurnikan

ekstrak air daun

Ekstrak buah

ekstrak lichen

Ekstrak daun

Ekstrak buah
$92.37-112.3$

$\mathrm{nm}$

5-10 nm

$30-40 \mathrm{~nm}$

$29 \mathrm{~nm}$

$80 \mathrm{~nm}$

$12.8 \mathrm{~nm}$ dan

$42.2 \mathrm{~nm}$

$8.66 \mathrm{~nm}$ dan

$60.7 \mathrm{~nm}$

$51 \mathrm{~nm}$

$19 \mathrm{~nm}$

5-20 nm

$10-40 \mathrm{~nm}$

20-80 nm

49,5 hingga

$82,4 \mathrm{~nm}$

4-95 nm

20-50 nm

$50 \mathrm{~nm}$

$30-50 \mathrm{~nm}$

$9-18 \mathrm{~nm}$

$15-22 \mathrm{~nm}$

$20-40 \mathrm{~nm}$

$54 \mathrm{~nm}$

$14.5 \mathrm{~nm}$

20-100 nm
(Usman et al., 2019)

(Szcs et al., 2019)

(Wang et al., 2019)

(Das \& Bhuyan et al., 2019)

(Boomi et al., 2019)

(Dzimitrowicz et al., 2019)

(Dzimitrowicz et al., 2019)

(Dzimitrowicz et al., 2019)

(Filip et al., 2019)

(Shamprasad et al., 2019)

(Patil, Bayaraa, et al., 2019)

(Chellapandian et al., 2019)

(Katas et al., 2019)

(Khoshnamvand et al., 2019)

(Patil et al., 2019)

(Mariychuk et al., 2019)

(Qian et al., 2019)

(Boldeiu et al., 2019)

(Balasubramanian et al., 2019)

(Nishanthi et al., 2019)

(Gandhi et al., 2019)

(Zayadi et al., 2019)

(Chokkalingam et al., 2019)
Tahap selanjutnya setelah sintesis nanopartikel adalah mengkarakterisasi ukuran dan morfologinya. Pada umumnya, AuNP dikarakterisasi dengan menggunakan Spektroskopi UV-VIS, Transmission Electron
Microscopy (TEM), Scanning Electron Microscopy (SEM).

Dasar spektroskopi UV-Vis adalah serapan cahaya, radiasi cahaya atau elektromagnet dapat dianggap menyerupai gelombang. Bila cahaya 
jatuh pada senyawa, maka sebagian dari cahaya diserap oleh molekul-molekul sesuai dengan struktur dari molekul senyawa tersebut. Serapan cahaya oleh molekul dalam daerah spektrum UVVis bergantung pada struktur elektronik dari molekul (Underwood, 2002). Interaksi AuNP dengan cahaya sangat ditentukan oleh lingkungan, ukuran dan dimensi fisiknya. Medan listrik berosilasi dari berkas cahaya yang merambat di dekat partikel nano koloid berinteraksi dengan elektron bebas menyebabkan pergerakan bersama muatan elektron yang beresonansi dengan frekuensi cahaya tampak. Osilasi resonansi ini dikenal sebagai plasmon permukaan. Untuk AuNP monodisperse kecil ( $30 \mathrm{~nm})$, fenomena resonansi plasmon permukaan menyebabkan penyerapan cahaya pada bagian biru-hijau dari spektrum $(\sim 450 \mathrm{~nm})$ sementara cahaya merah $(\sim 700 \mathrm{~nm})$ dipantulkan, menghasilkan warna merah. Dengan meningkatnya ukuran partikel, panjang gelombang penyerapan resonansi plasmon permukaan bergeser ke panjang gelombang yang lebih panjang dan lebih merah. Cahaya merah kemudian diserap, dan cahaya biru dipantulkan, menghasilkan larutan dengan warna biru pucat atau ungu. Variasi warna yang menunjukkan perbedaan ukuran partikel AuNP ditunjukkan pada Gambar 1. Ketika ukuran partikel terus meningkat, panjang gelombang resonansi plasmon permukaan bergerak ke daerah spektrum infra merah dan warna berubah sesuai panjang gelombangnya.
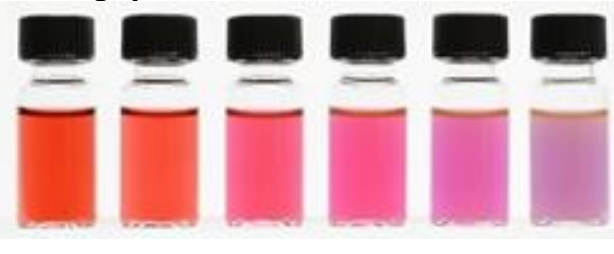

Gambar 1. Variasi warna yang timbul pada sintesis AuNP dengan makin meningkatnya ukuran partikel (Wang, dkk., 2011)

Identifikasi terbentuknya AuNP melalui analisis spektrofotometri UV-Vis ditunjukkan dengan adanya panjang gelombang maksimum sekitar 500-600 nm bergantung pada ukuran partikel. Pergeseran panjang gelombang maksimum dipengaruhi oleh ukuran partikel sebagaimana disajikan melalui Gambar 2.

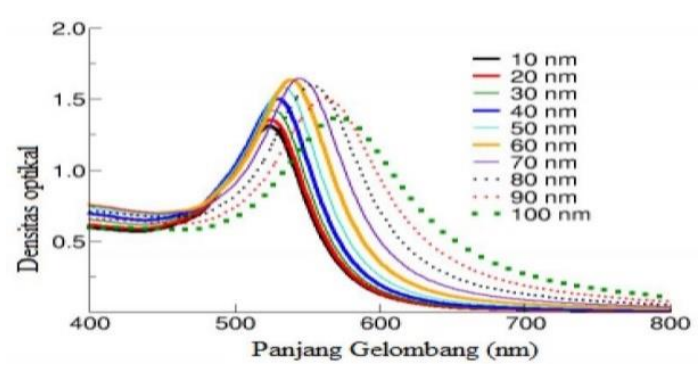

Gambar 2. Pengaruh ukuran nanopartikel pada spektrofotometer UV-Vis (Fatimah, 2014).

Transmission Electron Microscopy (TEM) dan Scanning Electron Microscopy (SEM) secara luas dianggap sebagai standar yang baik untuk mengkarakterisasi nanopartikel. TEM adalah sebuah mikroskop elektron dengan cara kerjanya mirip proyektor slide, dimana elektron ditembuskan ke dalam obyek pengamatan dan pengamat mengamati hasil tembusannya pada layar (Karlik, 2001). Karakterisasi dengan TEM digunakan untuk menentukan ukuran partikel dan distribusinya. Partikel dengan ukuran beberapa nanometer dapat diamati dengan jelas menggunakan TEM karena resolusinya yang sangat tinggi. Penggunaan high resolution TEM (HR-TEM) dapat membantu dalam menentukan lokasi atom-atom dalam sampel seperti ditunjukkan pada Gambar 3 (Egerton, 2010).

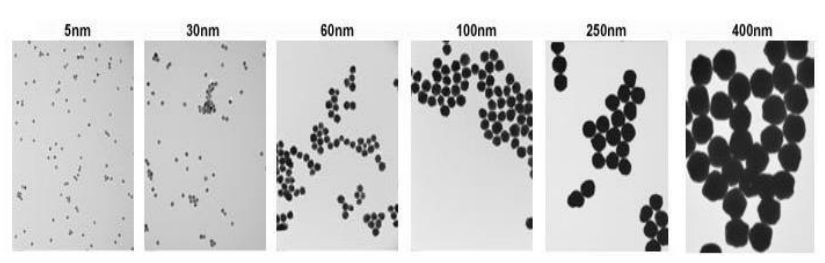

Gambar 3. Ukuran AuNP mulai dari $5 \mathrm{~nm}$ (kiri) hingga $400 \mathrm{~nm}$ (kanan) hasil proyeksi TEM, dengan koefisien variansi <8\% (Egerton, 2010).

SEM adalah jenis mikroskop elektron yang mencitrakan permukaan sampel oleh pemindaian dengan pancaran tinggi elektron. Elektron yang berinteraksi dengan atom yang membentuk sampel menghasilkan sinyal yang berisi informasi tentang sampel dari permukaan topografi, komposisi dan sifat lainnya sepertidaya konduksi listrik (Kutchko \& Kim, 2006)..

Rohiman et al menjelaskan mengenai pengaruh penambahan natrium sitrat dalam sintesis AuNP yang dapat mempengaruhi bentuk 
AuNP yang dihasilkan. Semakin banyak natrium sitrat yang ditambahkan maka seharusnya akan semakin banyak $\mathrm{AuCl}^{4-}$ yang tereduksi menjadi $\mathrm{Au}^{0}$ dengan ukuran kecil, karena natrium sitrat berfungsi sebagai agen pereduksi. Akan tetapi, berdasarkan data hasil karakterisasi SEM, diameter AuNP malah semakin besar seiring dengan penambahan natrium sitrat, seperti tampak pada Gambar 4. Hal ini terjadi kemungkinan karena kelebihan natrium sitrat dapat berfungsi sebagai penstabil selain sebagai agen pereduksi, sehingga akan melindungi AuNP seperti halnya konsep pembentukan misel pada sabun (surfaktan) dengan kotoran/noda. Oleh karena itu, AuNP yang dihasilkan membentuk

\section{KONJUGASI AUNP DENGAN BIOMOLEKUL (BIOKONJUGAT)}

Konjugasi AuNP-biomolekul dapat menyatukan sifat dan fungsi unik fisikokimia dari AuNP (misalnya, pita serapan plasmon yang kuat dan hamburan cahaya) dengan kemampuan molekul biologis untuk mencapai pengikatan dengan spesifisitas yang tinggi. Kombinasi antara AuNP dan biomolekul menghasilkan efek sinergis atau kooperatif. AuNP dapat memberikan peningkatan stabilitas pada protein dan kapasitas multivalen tambahan pada biomolekul yang terikat (Garc, 2013).

Menurut Delong et al. fungsionalisasi pada nanopartikel bertujuan untuk meningktakan stabilitas, fungsionalitas, dan biokompatibilitasnya. Namun terdapat tujuan utama dalam fungsionalisasi yaitu untuk menstabilkan sifat-sifat AuNP dan molekul biologi yang terikat. Dengan hal lain, molekul biologis dapat lebih stabil dan mampu mempertahankan sifat biorekognisinya sedangkan AuNP dapat mempertahankan sifat uniknya seperti pita serapan plasmon yang kuat, hamburan cahaya. Beberapa biomolekul yang telah dikonjugasikan dengan AuNP diantaranya protein, DNA, lipid dan karbohidrat seperti yang ditunjukkan pada Gambar 5. kelompok atau unit yang dilingkupi oleh sitrat sehingga yang teramati pada foto SEM, berdiameter lebih besar.

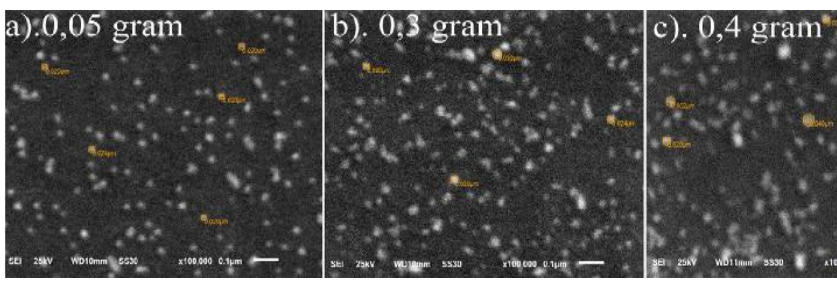

Gambar 4. Foto SEM yang menunjukkan pengaruh penambahan massa natrium sitrat terhadap ukuran diameter AuNPs yang terbentuk (Rohiman et al., 2014

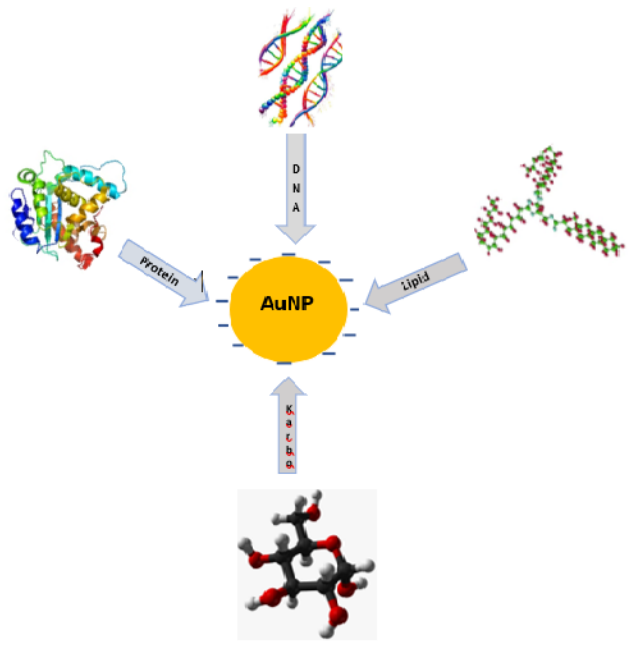

Gambar 5. Konjugasi AuNP dengan biomolekul (biokonjugat)

Proses pengikatan AuNP dengan biomolekul diantaranya melalui interaksi elektrostatik antara AuNP dan molekul biologis. Cara ini adalah salah satu cara termudah untuk memfungsikan dan menstabilkan biokonjugasi AuNP. Sebagai contoh, ketika AuNP bermuatan positif akan terikat melalui interaksi ionik yang stabil ke bagian bermuatan negatif dan nukleofilik. Molekul biologis yang mengandung gugus asam dan basa simultan (misalnya, protein) efisien dalam menstabilkan AuNP. Secara umum, stabilisasi AuNP oleh molekul biologis terjadi melalui adsorpsi molekul biologis secara pasif ke permukaan nanopartikel oleh elektrostatik dan interaksi hidrofobik (Mirau et al., 2017). 
Gambar 6 menelaskan interaksi molekul biologis (protein) pada permukaan AuNP. Penambahan protein ke dalam larutan AuNPs yang tertutup sitrat akan menghasilkan adsorpsi spontan protein ini pada permukaan AuNP karena elektrostatik, hidrofobik, dan interaksi Van der Waals (Garc et al., 2013).
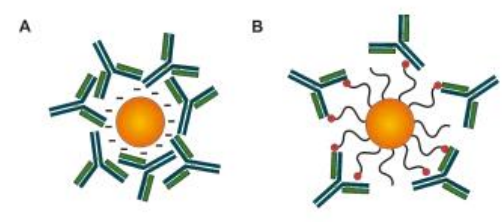

c
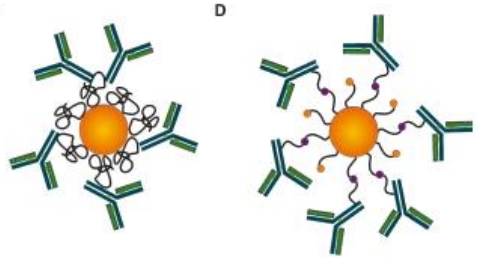

Gambar 6. Representasi skematis dan strategi umum untuk menghubungkan antibodi dengan AuNP (a) Adsorpsi antibodi melalui interaksi elektrostatik, hidrofobik dan Van der Waals. (b) Aktivasi kelompok terminal karboksilat dari NP (merah) dan penggabungan ke amina primer dari Antibodi (c) Fungsionalisasi NP dengan protein (pA atau $\mathrm{pG}$ ) yang memiliki afinitas pengikatan tinggi untuk wilayah Antibodi. (d) Oksidasi rantai oligosakarida Antibodi untuk penambahan gugus fungsi (violet) dan reaksi dengan gugus fungsi dalam NP (orange) (Garc, 2013).

Selain dengan DNA dan protein, AuNP telah dikonjugasikan juga dengan lipid dan karbohidrat. Gambar 7 menunjukkan penggunaan asam lemak oleat dan fosfatidilkolin untuk melapisi AuNP membentuk biokonjugat dalam aplikasi biosensor surface plamon resonance (SPR). Terdapat tiga jenis interaksi nanopartikel dengan membran lipid yakni elektrostatik, dimana nanopartikel terikat pada permukaan membran oleh gaya elektrostatik sederhana, interaksi van der Waals, dan interaksi melibatkan partikel hidrofobik yang tertanam ke dalam inti membran seperti yang dijelaskan pada Gambar 7 (Cai, 2015).

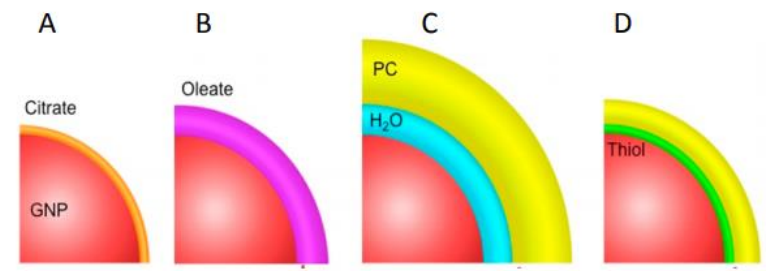

Gambar 7. Proses pelapisan lipid. (a) AuNP dilapisi sitrat. (b) AuNP dilapisi oleat dengan penambahan natrium oleat. (c) AuNP dilapisi dengan fosfatidilkolin dengan penambahan PC30. (d) propanatiol meresap melalui lapisan fosfatidilkolin dan melapisi nanosfer emas.

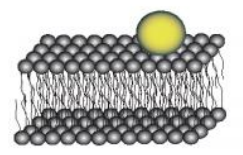

(A)

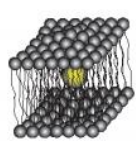

(B)

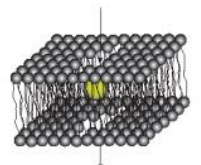

(C)
Gambar 8. Interaksi antara lipid dengan nanopartikel: (a) Interaksi elektrostatik, nanopartikel terikat pada permukaan membran oleh gaya elektrostatik sederhana. (b) interaksi Van der Waals dan efek hidrofobik (c) melibatkan kombinasi kompleks (a) dan (b), nanopartikel berpartisi ke dalam kedua lapisan (bilayers) tetapi dilepaskan ke sisi lain (Derrien, 2009)

\section{KONJUGASI AuNP DENGAN DNA}

Asam nukleat adalah polimer nukleotida yang tersusun secara sistematis dari gula-basa nitrogenfosfat. Fungsi utamanya untuk menyimpan, mereplikasi dan mentransmisikan informasi genetik dalam sistem biologis (Niu et al., 2018). Jenis polinukleotida ini di antaranya DNA (deoxyribonucleic acid), RNA (ribonucleic acid), dan juga aptamer. Aptamer merupakan oligonukleotida RNA atau DNA rantai tunggal sintetik yang diseleksi melalui metode in vitro yang dikenal sebagai Systematic Evolution of Ligands by Exponential enrichment (SELEX).

DNA, RNA, maupun aptamer, telah banyak dikonjugasikan dengan AuNP dan digunakan dalam aplikasi analisis, diagnosis, maupun teurapetik. Pada saat nukleotida terkonjugasi dengan AuNP, stabilitas dan efisiensi absorpsi keduanya meningkat. Contohnya aptamer-AuNP cocok untuk aplikasi biomedis seperti antikoagulasi, antikanker, antibakteri, dan 
antivirus. Begitupula DNA-AuNP maupun RNAAuNP, telah banyak dilaporkan berbagai macam aplikasinya. Ketiga jenis oligonukleotida ini berinteraksi dengan AuNP melalui berbagai cara pengikatan.

Sebagian besar konjugasi DNA-AuNP dicapai melalui ikatan Au-Sdengan cara DNA dimodifikasi dengan menambahkan gugus tiol pada ujung 5' atau 3'nya. Konjugasi DNA-AuNP pertama dilaporkan oleh Mirkin et al. [111] Mereka merancang dua jenis AuNP, masingmasing terkonjugasi dengan oligonukleotida untai tunggal yang berbeda yang saling melengkapi satu sama lain. Berdasarkan hibridisasi dari dua oligonukleotida, perakitan AuNP mengarah pada emisi yang diinduksi agregasi dalam warna merah sebagai output sinyal. Pendekatan ini memberikan batas deteksi hingga tingkat nanomolar untuk deteksi DNA, bahkan dengan resolusi untuk mengenali ketidaksesuaian basa tunggal. Stabilitas dan efisiensi hibridisasi DNAAuNP sangat bergantung pada kepadatan permukaan DNA. Ketika kepadatan DNA pada permukaan AuNPs terlalu tinggi, hilangnya fungsi biologis mungkin terjadi sebagai akibat dari efek sterik. Dengan demikian, kepadatan permukaan ligan DNA pada AuNP harus dioptimalkan. Untuk mendapatkan DNA-AuNP yang stabil, perendaman garam dengan $100 \mathrm{~mm}$ $\mathrm{NaCl}$ direkomendasikan. Selain itu, DNA yang terdiri dari basa pengenalan dan basa terminal seperti polythymine disarankan untuk memberikan efisiensi hibridisasi yang lebih tinggi dan meminimalkan efek permukaan (Wang et al., 2016; Sutter et al., 2019; Torabi \& Lu, 2014; Delong et al., 2010; Liu \& Liu, 2017). Liu \& Liu, 2017 menjelaskan mengenai fungsionalisasi AuNP dengan DNA yang tertiolasi seperti yang ditunjukkan pada Gambar 9 (Liu \& Liu, 2017). DNA dengan AuNP: (a) Kerapatan DNA yang rendah cenderung membungkus permukaan $\mathrm{Au}$, dan DNA tidak dapat berhibridisasi. (b) Proses penambahan garam melibatkan adsorpsi DNA awal, dan peningkatan konsentrasi $\mathrm{NaCl}$ secara bertahap. (c) Pemasangan DNA dengan adanya ligan penstabil (mis., Surfaktan) untuk meningkatkan stabilitas koloidal AuNPs. (d) Penaggunaan $\mathrm{pH}$ rendah membutuhkan DNA yang mengandung blok poli untuk berkumpul menjadi dupleks paralel. (e) Metode pembekuan tidak memerlukan reagen tambahan. (f) Penahan poli (A) yang mengandung DNA nonthiolasi pada AuNP dengan kepadatan terkontrol; blok poli (a) yang lebih panjang menghasilkan kepadatan DNA yang lebih rendah (Liu \& Liu, 2017).

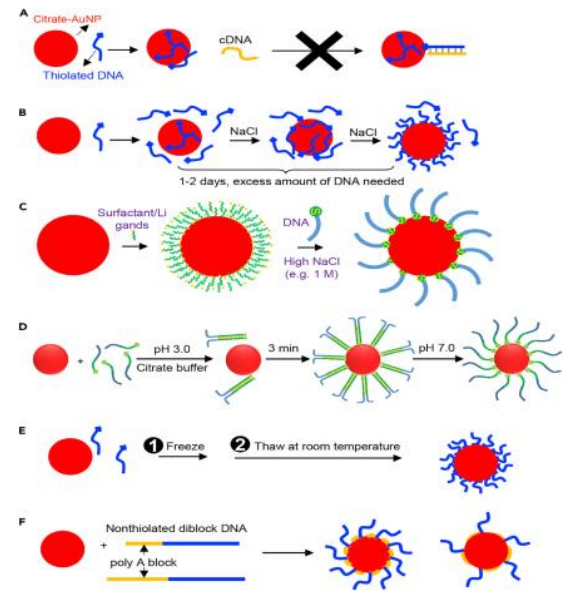

Gambar 9. metode dalam pengkonjugasian

Selain menggunakan linker gugus tiol, konjugasi AuNP-DNA juga dapat dilakukan melalui penambahan linker streptavidin-biotin seperti yang dilakukan oleh (Poturnayová et al., 2019; D’Agata et al., 2017; Liu et al., 2012). Dalam penelitiannya, D'Agata et al. JM7 menggunakan biokonjugat AuNP-aptamer yang terbiotinilasi dengan menggunakan linker streptavidin. Adanya streptavidin akan meningkatkan daya ikat pada biokonjugat dan meningkatkan kestabilan AuNP. Streptavidin akan berikatan dengan AuNP secara adsorpsi dimana muatan negative AuNP yang distabilkan oleh natrium sitrat akan berikatan dengan muatan positif yang ada pada residu asam amino streptavidin. AuNP yang telah terikat streptavidin akan berikatan dengan DNA yang terbiotinilasi dimana ikatan streptavidin dan biotin ini sangat spesifik seperti protein dan ligan. Ilustrasi dari biokonjugat ini dapat dilihat pada Gambar 10.

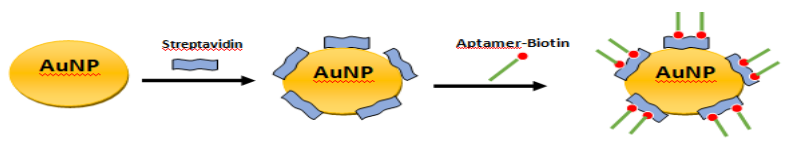

Gambar 10. Pembentukan biokonjugat AuNPApt-biotin-streptavidin (D'Agata et al., 2017). 


\section{APLIKASI BIOKONJUGAT AUNP - DNA DALAM BIOSENSOR ELEKTROKIMIA}

Metode elektrokimia telah menarik banyak perhatian dalam bidang diagnostik klinis karena cepat, sederhana, sensitif, deteksi biaya rendah, serta memberikan kemudahan dalam miniaturisasi (Charbgoo et al., 2017). Strategi biokonjugasi yang cocok dan stabilisasi biomolekul pada elektrode sangat penting untuk pengembangan biosensor yang baru dan layak secara komersial (Li \& Drago, 2016). Aptamer DNA telah digunakan sebagai elemen pengenal dalam sensor dengan interaksi antara molekul DNA dan logam. Konduktivitas yang sangat baik, luas permukaan yang tinggi dan sifat katalitik AuNP menjadikannya kandidat utama untuk deteksi elektrokimia dari berbagai analit. Karena sensitivitasnya yang tinggi, respons yang cepat, dan ketahanannya, deteksi elektrokimia berbasis aptasensor semakin menarik perhatian. Dari sejak 1990-an, aptamer telah digunakan sebagai elemen pengenal untuk biosensor elektrokimia. DNA terfungsionalisasi AuNP (DNA-AuNP) telah menunjukkan potensi besar untuk biosensing karena memiliki sifat optik yang sangat baik dari AuNP dan fungsi pengenalan molekul DNA (Rashid \& Yusof, 2017).

Aspek yang paling banyak dipelajari dari interaksi DNA-AuNP adalah kinetika adsorpsi dan termodinamika strands-DNA dengan AuNP. Terdapat beberapa pendapat mengenai interaksi adsorpsi DNA yang menyimpulkan bahwa prosesnya didominasi oleh interaksi hidrofobik dan interaksi hidrofilik. Interaksi aptamer dengan AuNP sangat kompleks karena interaksi keduanya menggunakan struktur terlipat sebagian dengan loop dan untai ganda yang dilipat menjadi struktur tiga dimensi. Dengan perubahan struktur yang terjadi dapat meningkatkan pengikatan target yang tidak mewakili baik ss-DNA atau dsDNA (Mirau et al., 2017) .

Dalam dua tahun terakhir terdapat beberapa peneliti yang menggunakan biokonjugat AuNPDNA sebagai pendekatan dalam pendeteksian target menggunakan biosensor elektrokimia. Pada tahun 2019, Dai et al. melakukan suatu pengujian berbasis aptamer kompetitif untuk deteksi S.typhimurium dibuat dengan menggabungkan UiO-67/GR dan probe cDNA dengan nanopartikel aptamer-emas (AuNPs) (AptAuNPs-HRP). DNA komplementer parsial terminal (cDNA) aptamer dimodifikasi secara kovalen pada elektrode melalui koordinasi yang kuat antara gugus fosfat dan $\mathrm{Zr}-\mathrm{OH}$ dari UiO-67. Aptamer akan mengikat erat dengan $S$. typhimurium untuk membentuk kompleks aptamer-AuNPs-HRP/S. typhimurium. Dengan demikian, nanoprobe Apt-AuNPs-HRP tidak mampu memuat pada elektrode yang dimodifikasi sehingga membuat respon yang tertangkap sedikit. Dengan tidak adanya $S$. typhimurium, aptamer tertiolasi yang diimobilisasi pada AuNPs akan berhibridisasi dengan cDNA capture probe. Jumlah HRP pada permukaan elektroda kemudian meningkat, dan sinyal elektrokimia besar diperoleh dengan katalisis HRP dalam sistem HQ $+\mathrm{H}_{2} \mathrm{O}_{2}$. Nilai sensitivitas tinggi yang dihasilkan berasal dari sifat luar biasa dari probe amplifikasi sinyal UiO-67/GR dan Apt-AuNPs-HRP. Dalam hal ini menunjukkan bahwa pendekatan aplikasi prospektif komposit UiO-67/GR dalam pengujian berbasis aptamer dapat meningkatkan nilai sensitivitas pada pendeteksian $S$. typhimurium terdeteksi dalam rentang linier $2 \times 10^{1}-2 \times 10^{8}$ $\mathrm{cfu} / \mathrm{mL}$, dengan batas deteksi lebih rendah dari 5 cfu/mL. Gambar 11 menunjukkan penggunaan biokonjugat aptamer-AuNP dalam biosensor elektrokimia untuk mendeteksi S. typhimurium

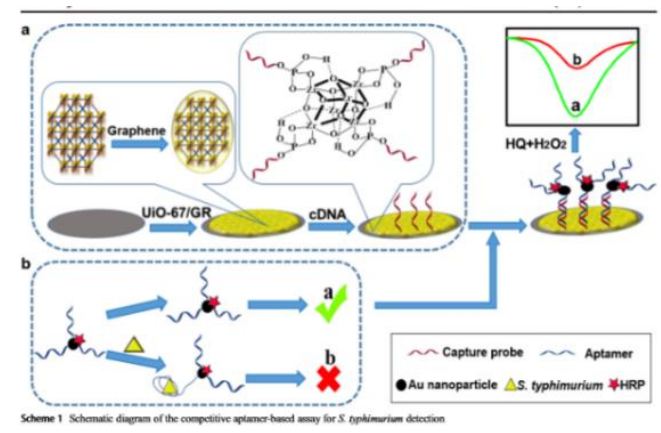

Gambar 11. Pengujian berbasis aptamer kompetitif untuk S. typhimurium (Dai et al., 2019)

Biokonjugat AuNP-DNA pada biosensor elektrokimia juga telah dikembangkan oleh Hartati et al. yang menggunakan DNA tertiolasi (DNA-SH) yang akan teradsorpsi oleh AuNP membentuk Self Assembled monolayer (SAM) yang dapat mengontrol permukaan AuNP. Biokonjugat AuNP-DNA-SH akan terbentuk melalui interaksi kovalen yang kuat antara sulfur pada gugus tiol dengan permukaan AuNP. 
Dengan menggunakan biokonjugat ini pendeteksian akan lebih selektif dan respon yang didapatkan baik. Sensor elektrokimia yang digunakan adalah elektroda SPCE dengan modifikasi emas. Proses imobilisasi biokonjugat AuNP-DNA pada permukaan SPCE melibatkan MPA sebagai penghubung. Kelompok thiol (SH) MPA digunakan sebagai situs pengikatan ikatan kovalen dengan nanopartikel logam, sedangkan kelompok karboksilat $(-\mathrm{COOH})$ digunakan untuk bereaksi secara kovalen dengan gugus fosfat dalam DNA untuk mencapai imobilisasi yang efektif. Kelompok karboksilat MPA diaktifkan oleh EDC dan NHS sehingga terbentuk ester suksinimida yang digunakan untuk amobilisasi biokonjugat pada permukaan SPCE. DNA target diamati berdasarkan sinyal indikator MB.

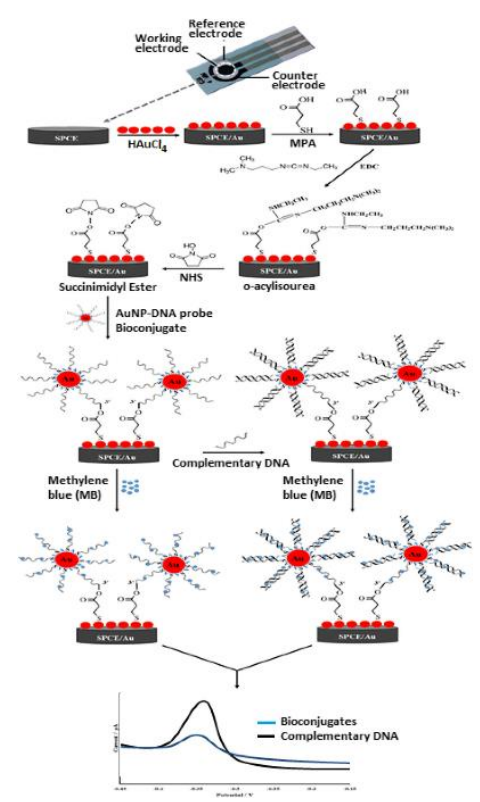

Gambar 12. Skema biosensor DNA berdasarkan biokonjugat AuNP-DNA probe pada permukaan SPCE-Emas, dengan deteksi menggunakan metilen biru (Hartati et al., 2019).
Sinyal elektrokimia MB yang terikat pada dsDNA ditentukan oleh jarak transfer elektron dari molekul MB ke elektroda. Pendeteksian ini menghasilkan nilai LoD sebesar $0,58 \mu \mathrm{g} / \mathrm{mL}$ dan Recoverynya adalah $101,74 \%$. Skema keseluruhan biosensor elektrokimia dengan menggunakan biokonjugat AuNP-DNA ini ditunjukkkan pada Gambar 12. Penggunaan biokonjugat AuNP-DNA dalam aplikasinya sebagai biosensor elektrokimia yang dilaporkan dalam dua tahun terkahir ditunjukkan dalam Tabel 2.

\section{KESIMPULAN}

Aplikasi AuNP telah berkembang pesat dalam dekade ini karna terbukti bahwa penggunaan nanopartikel emas merupakan suatu pendekatan yang sangat baik. Dari data yang kami kumpulkan, peningkatan publikasi yang cepat dalam tiga tahun terakhir adalah sintesis nanopartikel emas dengan metode biologi. Nanopartikel emas juga memiliki kemampuan yang sangat baik dalam berkonjugasi dengan DNA karena dalam aplikasinya terhadap biosensor elektrokimia dapat meningkatkan nilai sensitivitas dan selektifitas. 
Tabel 2. Penggunaan biokonjugat AuNP-DNA dalam biosensor elektrokimia pada tahun 2018-2019

\begin{tabular}{|c|c|c|c|c|}
\hline $\begin{array}{l}\text { Judul } \\
\end{array}$ & Biokonjugat & Target & LoD & Refrensi \\
\hline $\begin{array}{l}\text { Approaching single DNA molecule } \\
\text { detection with an ultrasensitive } \\
\text { electrochemical genosensor based on gold } \\
\text { nanoparticles and Cobalt-porphyrin DNA } \\
\text { conjugates }\end{array}$ & $\begin{array}{l}\text { AuNPs-CoP- } \\
\text { ssDNA }\end{array}$ & $\begin{array}{l}\text { single nucleotide } \\
\text { polymorphism } \\
\text { (SNP) }\end{array}$ & $\begin{array}{l}4.8 \times 10-17 \\
\mathrm{mM}\end{array}$ & $\begin{array}{l}\text { (Kaur et } \\
\text { al., 2018) }\end{array}$ \\
\hline $\begin{array}{l}\text { A Gold Nanoparticle- DNA Bioconjugate- } \\
\text { Based Electrochemical } \\
\text { Biosensor for Detection of Sus scrofa } \\
\text { mtDNA in Raw and Processed } \\
\text { Meat }\end{array}$ & AuNP-DNA probe & $\begin{array}{ll}\text { Sus } & \text { scrofa } \\
\text { mtDNA } & \end{array}$ & $0.58 \mu \mathrm{g} / \mathrm{mL}$ & $\begin{array}{l}\text { (Hartati } \\
\text { et al., } \\
2019)\end{array}$ \\
\hline $\begin{array}{l}\text { An ultrasensitive electrochemical biosensor } \\
\text { for polynucleotide kinase assay based on } \\
\text { gold nanoparticle-mediated lambda } \\
\text { exonuclease cleavage-induced signal } \\
\text { amplification }\end{array}$ & $\begin{array}{l}\text { AuNP-DNA strand } \\
2\end{array}$ & $\begin{array}{l}\text { polynucleotide } \\
\text { kinase }\end{array}$ & $\begin{array}{l}7.76 \times 10-4 \\
\mathrm{U} / \mathrm{mL}\end{array}$ & $\begin{array}{l}\text { (Cui et } \\
\text { al., 2018) }\end{array}$ \\
\hline $\begin{array}{l}\text { A Novel Electrochemical Aptamer } \\
\text { Biosensor Based on DNAzyme Decorated } \\
\text { Au@ Ag } \\
\text { Core-Shell Nanoparticles for Hg2+ } \\
\text { Determination }\end{array}$ & $\begin{array}{l}\text { AuNP@AgNP- } \\
\text { DNAzyme }\end{array}$ & $\mathrm{Hg}^{2+}$ & $0.006 \mu \mathrm{g} / \mathrm{L}$ & $\begin{array}{l}\text { (Zhao \& } \\
\text { Xie, et } \\
\text { al., 2018) }\end{array}$ \\
\hline $\begin{array}{l}\text { Electrochemical determination of } \\
\text { Salmonella typhimurium } \\
\text { by using aptamer-loaded gold nanoparticles } \\
\text { and a composite } \\
\text { prepared from a metal-organic framework } \\
\text { (type UiO-67) and grapheme }\end{array}$ & Apt-AuNPs-HRP & $\begin{array}{l}\text { Salmonella } \\
\text { typhimurium }\end{array}$ & $\begin{array}{l}5 \mathrm{cfu} / \mathrm{mL} \\
\text { (based on } \\
\mathrm{S} / \mathrm{N}=3 \text { ) }\end{array}$ & $\begin{array}{l}\text { (Dai et } \\
\text { al., 2019) }\end{array}$ \\
\hline $\begin{array}{l}\text { Aptamer-Functionalized and Gold } \\
\text { Nanoparticle Array-Decorated Magnetic } \\
\text { Graphene Nanosheets Enable Multiplexed } \\
\text { and Sensitive Electrochemical Detection of } \\
\text { Rare Circulating Tumor Cells in Whole } \\
\text { Blood }\end{array}$ & $\begin{array}{l}\text { Apt/AuNPs- } \\
\text { Fe3O4-GS }\end{array}$ & $\begin{array}{l}\text { CTC } \\
\text { (Circulating } \\
\text { Tumor Cells) }\end{array}$ & $\begin{array}{l}4 \text { and } 3 \\
\text { (cells/mL) }\end{array}$ & $\begin{array}{l}\text { (Dou et } \\
\text { al., 2019) }\end{array}$ \\
\hline
\end{tabular}




\section{DAFTAR PUSTAKA}

Abdelghany, A.M., Oraby, A.H., \& Asnag, G.M. (2019) Structural, thermal and electrical studies of polyethylene oxide/starch blend containing green synthesized gold nanoparticles. Journal of Molecular Structure. 1180, 15-25.

Ahmad, T., Bustam, M.A., Irfan, M., Moniruzzaman, M., Anwaar Asghar, H.M., \& Bhattacharjee, S. (2018) Green synthesis of stabilized spherical shaped gold nanoparticles using novel aqueous Elaeis guineensis (oil palm) leaves extract. Journal of Molecular Structure. 1159, 167-173.

Aljabali, A., Akkam, Y., Al Zoubi, M., Al-Batayneh, K., Al-Trad, B., Abo Alrob, O., Alkilany, A., Benamara, M., \& Evans, D. (2018) Synthesis of Gold Nanoparticles Using Leaf Extract of Ziziphus zizyphus and their Antimicrobial Activity. Nanomaterials. 8(3), 174.

Anon (2009) Gold Nanoparticle-Lipid Bilayer Interactions Thomas Derrien.

Asnag, G.M., Oraby, A.H., \& Abdelghany, A.M. (2019) Green synthesis of gold nanoparticles and its effect on the optical, thermal and electrical properties of carboxymethyl cellulose. Composites Part B: Engineering. 172(February), 436-446.

Babaei, Z., Faridi, R., Negahdari, B., \& Tavoosidana, G. (2018) ' Inversed Turkevich' method for tuning the size of Gold nanoparticles : evaluation the effect of concentration and temperature. Nanomedicine Res J. 3(4), 190-196.

Baer, D. R., Engelhard, M. H., Johnson, G. E., Laskin, J., Lai, J., Mueller, K., ... Moon, D. (2013). Surface characterization of nanomaterials and nanoparticles: Important needs and challenging opportunities. Journal of Vacuum Science \& Technology A: Vacuum, Surfaces, and Films, 31(5), 050820. doi:10.1116/1.4818423

Balasubramanian, S., Kala, S.M.J., Pushparaj, T.L., \& Kumar, P.V. (2019) Biofabrication of gold nanoparticles using cressa cretica leaf extract and evaluation of catalytic and antibacterial efficacy. Nano Biomedicine and Engineering. 11(1), 58-66.

Baruah, D., Goswami, M., Yadav, R.N.S., Yadav, A., \& Das, A.M. (2018) Biogenic synthesis of gold nanoparticles and their application in photocatalytic degradation of toxic dyes. Journal of Photochemistry and Photobiology B: Biology. 186, 51-58.

Benedec, D., Oniga, I., Cuibus, F., Sevastre, B., Stiufiuc, G., Duma, M., Hanganu, D., Iacovita, C., Stiufiuc, R., \& Lucaciu, C.M. (2018) Origanum vulgare mediated green synthesis of biocompatible gold nanoparticles simultaneously possessing plasmonic, antioxidant and antimicrobial properties. International Journal of Nanomedicine. 13, 10411058.

Biao, L., Tan, S., Meng, Q., Gao, J., Zhang, X., Liu,
Z., \& Fu, Y. (2018) Green synthesis, characterization and application of proanthocyanidins-functionalized gold nanoparticles. Nanomaterials. 8(1).

Biju, V. (2014) Chemical modifications and bioconjugate reactions of nanomaterials for sensing, imaging, drug delivery and therapy. Chem. Soc. Rev.. 43(3), 744-764.

Bogireddy, N.K.R., Pal, U., Gomez, L.M., \& Agarwal, V. (2018) Size controlled green synthesis of gold nanoparticles using Coffea arabica seed extract and their catalytic performance in 4-nitrophenol reduction. RSC Advances. 8(44), 24819-24826.

Boldeiu, A., Simion, M., Mihalache, I., Radoi, A., Banu, M., Varasteanu, P., Nadejde, P., Vasile, E., Acasandrei, A., Popescu, R.C., Savu, D., \& Kusko, M. (2019) Comparative analysis of honey and citrate stabilized gold nanoparticles: In vitro interaction with proteins and toxicity studies. Journal of Photochemistry and Photobiology B: Biology. 197(May), 111519.

Boomi, P., Ganesan, R.M., Poorani, G., Gurumallesh Prabu, H., Ravikumar, S., \& Jeyakanthan, J. (2019) Biological synergy of greener gold nanoparticles by using Coleus aromaticus leaf extract. Materials Science and Engineering C. 99(January), 202-210.

Brust, M., Walker, M., Bethell, D., Schiffrin, D.J., \& Whyman, R. (2000) Synthesis of Thiol-derivatised Gold Nanoparticles in. , 801-802.

Cai, Y. (2015) Lipid-Coated Gold Nanoparticle as a Biosensor for Lipid-Protein Interactions.

Chandran, K., Song, S., \& Yun, S.-I. (2014) Effect of size and shape controlled biogenic synthesis of gold nanoparticles and their mode of interactions against food borne bacterial pathogens. Arabian Journal of Chemistry. 12(8), 1994-2006.

Chandan Barai, A., Paul, K., Dey, A., Manna, S., Roy, S., Gopal Bag, B., \& Mukhopadhyay, C. (2018) Green synthesis of Nerium oleander-conjugated gold nanoparticles and study of its in vitro anticancer activity on MCF-7 cell lines and catalytic activity. Nano Convergence. 5, 10.

Charbgoo, F., Ramezani, M., \& Darroudi, M. (2017) Bio-sensing applications of cerium oxide nanoparticles: Advantages and disadvantages. Biosensors and Bioelectronics. 96, 33-43.

Chaudhuri, K., Chandan Barai, A., Das, S., Gopal Bag, B., Tapan Seal, C., Nurul Hasan, S., \& Seal, T. (2018) Nutraceutical evaluation of Rhynchotechum ellipticum, a potent wild edible plant consumed by the tribal of North-Eastern region in India and green synthesis of gold nanoparticles using its leaf extract. $\sim 1434 \sim$ Journal of Pharmacognosy and Phytochemistry. 7(3).

Chen, X., Zhao, X., Gao, Y., Yin, J., Bai, M., \& Wang, F. (2018) Green synthesis of gold nanoparticles using carrageenan oligosaccharide and their in vitro 
antitumor activity. Marine Drugs. 16(8).

Chellapandian, C., Ramkumar, B., Puja, P., Shanmuganathan, R., Pugazhendhi, A., \& Kumar, P. (2019) Gold nanoparticles using red seaweed Gracilaria verrucosa: Green synthesis, characterization and biocompatibility studies. Process Biochemistry. 80(February), 58-63.

Chokkalingam, M., Singh, P., Huo, Y., Soshnikova, V., Ahn, S., Kang, J., Mathiyalagan, R., Kim, Y.J., \& Yang, D.C. (2019) Facile synthesis of $\mathrm{Au}$ and Ag nanoparticles using fruit extract of Lycium chinense and their anticancer activity. Journal of Drug Delivery Science and Technology. 49, 308-315.

Cui, L., Li, Y., Lu, M., Tang, B., \& Zhang, C. yang (2018) An ultrasensitive electrochemical biosensor for polynucleotide kinase assay based on gold nanoparticle-mediated lambda exonuclease cleavage-induced signal amplification. Biosensors and Bioelectronics. 99, 1-7.

D’Agata, R., Palladino, P., \& Spoto, G. (2017)

Streptavidin-coated gold nanoparticles: Critical role of oligonucleotides on stability and fractal aggregation. Beilstein Journal of Nanotechnology. 8(1), 1-11.

Dai, G., Li, Z., Luo, F., Ai, S., Chen, B., \& Wang, Q. (2019) Electrochemical determination of

Salmonella typhimurium by using aptamer-loaded gold nanoparticles and a composite prepared from a metal-organic framework (type UiO-67) and graphene. Microchimica Acta. 186(9).

Dang, H., Fawcett, D., \& Poinern, G.E.J. (2019) Green synthesis of gold nanoparticles from waste macadamia nut shells and their antimicrobial activity against Escherichia coli and Staphylococcus epidermis. International Journal of Research in Medical Sciences. 7(4), 1171.

Das, R.K. \& Bhuyan, D. (2019) Microwave-mediated green synthesis of gold and silver nanoparticles from fruit peel aqueous extract of Solanum melongena L. and study of antimicrobial property of silver nanoparticles. Nanotechnology for Environmental Engineering. 4(1), 1-6.

Day, R A, dan Underwood, A L., (2002), Analsis Kimia Kuantitatif Edisi Keenam, Erlangga, Jakarta t Delong, R.K., Reynolds, C.M., Malcolm, Y., Schaeffer, A., Severs, T., \& Wanekaya, A. (2010) Functionalized gold nanoparticles for the binding , stabilization, and delivery of therapeutic DNA, RNA, and other biological macromolecules. , 53-63.

Delong, R.K., Reynolds, C.M., Malcolm, Y., Schaeffer, A., Severs, T., \& Wanekaya, A. (2010) Functionalized gold nanoparticles for the binding , stabilization, and delivery of therapeutic DNA , RNA, and other biological macromolecules. , 53-63. Dou, B., Xu, L., Jiang, B., Yuan, R., \& Xiang, Y.
(2019) Aptamer-functionalized and gold nanoparticle array-decorated magnetic graphene nanosheets enable multiplexed and sensitive electrochemical detection of rare circulating tumor cells in whole blood. Analytical Chemistry. 91(16), 10792-10799.

Divakaran, D., Lakkakula, J.R., Thakur, M., Kumawat, M.K., \& Srivastava, R. (2019) Dragon fruit extract capped gold nanoparticles: Synthesis and their differential cytotoxicity effect on breast cancer cells. Materials Letters. 236, 498-502.

Dzimitrowicz, A., Berent, S., Motyka, A., Jamroz, P., Kurcbach, K., Sledz, W., \& Pohl, P. (2019). Comparison of the characteristics of gold nanoparticles synthesized using aqueous plant extracts and natural plant essential oils of Eucalyptus globulus and Rosmarinus officinalis. Arabian Journal of Chemistry, 12(8), 4795-4805.

Dzimitrowicz, A., Berent, S., Motyka, A., Jamroz, P., Kurcbach, K., Sledz, W., \& Pohl, P. (2016) Comparison of the characteristics of gold nanoparticles synthesized using aqueous plant extracts and natural plant essential oils of Eucalyptus globulus and Rosmarinus officinalis. Arabian Journal of Chemistry.

Fatimah S.2009.Pengaruh uranium terhadap analisis menggunakanspektrofotometer UV-VIS. [Seminar Nasional]. Serpong (ID) BATAN

Filip, G.A., Moldovan, B., Baldea, I., Olteanu, D., Suharoschi, R., Decea, N., Cismaru, C.M., Gal, E., Cenariu, M., Clichici, S., \& David, L. (2019) UVlight mediated green synthesis of silver and gold nanoparticles using Cornelian cherry fruit extract and their comparative effects in experimental inflammation. Journal of Photochemistry and Photobiology B: Biology. 191(December 2018), 2637.

Egerton, R. \& Libera , M. R. (2010) Advances in the Transmission Electron Microscopy of polymers. Polymer Reviews, 50:321-339, 2010

Emami, M., Shamsipur, M., Saber, R., \& Irajirad, R. (2014) An electrochemical immunosensor for detection of a breast cancer biomarker based on antiHER2-iron oxide nanoparticle bioconjugates. The Analyst. 139(11), 2858-66.

Eskandari-Nojedehi, M., Jafarizadeh-Malmiri, H., \& Rahbar-Shahrouzi, J. (2018) Hydrothermal green synthesis of gold nanoparticles using mushroom (Agaricus bisporus) extract: Physico-chemical characteristics and antifungal activity studies. Green Processing and Synthesis. 7(1), 38-47.

Eskandari-Nojehdehi, M., Jafarizadeh-Malmiri, H., \& Jafarizad, A. (2018) Microwave Accelerated Green Synthesis of Gold Nanoparticles Using Gum Arabic and their Physico-Chemical Properties Assessments. Zeitschrift fur Physikalische Chemie. 232(3), 325- 
343.

Gangapuram, B.R., Bandi, R., Alle, M., Dadigala, R., Kotu, G.M., \& Guttena, V. (2018) Microwave assisted rapid green synthesis of gold nanoparticles using Annona squamosa L peel extract for the efficient catalytic reduction of organic pollutants. Journal of Molecular Structure. 1167, 305-315.

Gandhi, A.D., Murugan, K., Umamahesh, K., Babujanarthanam, R., Kavitha, P., \& Selvi, A. (2019) Lichen Parmelia sulcata mediated synthesis of gold nanoparticles: an eco-friendly tool against Anopheles stephensi and Aedes aegypti. Environmental Science and Pollution Research. 26(23), 23886-23898.

Garc, L. (2013) Introducing gold nanoparticle bioconjugates within the biological machinery. Thèse, 235.

Gopinath, V., Priyadarshini, S., MubarakAli, D., Loke, M.F., Thajuddin, N., Alharbi, N.S., Yadavalli, T., Alagiri, M., \& Vadivelu, J. (2019) Anti-Helicobacter pylori, cytotoxicity and catalytic activity of biosynthesized gold nanoparticles: Multifaceted application. Arabian Journal of Chemistry. 12(1), 33-40.

Gubitosa, J., Rizzi, V., Lopedota, A., Fini, P., Laurenzana, A., Fibbi, G., Fanelli, F., Petrella, A., Laquintana, V., Denora, N., Comparelli, R., \& Cosma, P. (2018) One pot environmental friendly synthesis of gold nanoparticles using Punica Granatum Juice: A novel antioxidant agent for future dermatological and cosmetic applications. Journal of Colloid and Interface Science. 521, 50-61.

Hamelian, M., Varmira, K., \& Veisi, H. (2018) Green synthesis and characterizations of gold nanoparticles using Thyme and survey cytotoxic effect, antibacterial and antioxidant potential. Journal of Photochemistry and Photobiology B: Biology. 184, 71-79.

Hamelian, M., Hemmati, S., Varmira, K., \& Veisi, H. (2018) Green synthesis, antibacterial, antioxidant and cytotoxic effect of gold nanoparticles using Pistacia Atlantica extract. Journal of the Taiwan Institute of Chemical Engineers. 93, 21-30.

Handayani, W., 2011, Pemanfaataan Tumbuhan Tropis untuk Biosintesis Nanopartikel Perak dan Aplikasinya Sebagai Indikator Kolorimetri Keberadaan Logam Berat, Tesis. Pascasarjana Program Studi Biologi FMIPA Universitas Indonesia

Hartati, Y.W., Suryani, A.A., Agustina, M., Gaffar, S., \& Anggraeni, A. (2019) A Gold Nanoparticle-DNA Bioconjugate-Based Electrochemical Biosensor for Detection of Sus scrofa mtDNA in Raw and Processed Meat. Food Analytical Methods. 12(11), 2591-2600.

Herizchi, R., Abbasi, E., Milani, M., \& Akbarzadeh, A. (2016) Current methods for synthesis of gold nanoparticles. Artificial Cells, Nanomedicine and Biotechnology. 44(2), 596-602.

Hu, M., Chen, J., Li, Z.Y., Au, L., Hartland, G. V., Li, X., Marquez, M., \& Xia, Y. (2006) Gold nanostructures: Engineering their plasmonic properties for biomedical applications. Chemical Society Reviews. 35(11), 1084-1094.

Huang, Q., Luo, A., Jiang, L., Zhou, Y., Yang, Y., Liu, Q., \& Zhang, C. (2019) Disinfection efficacy of green synthesized gold nanoparticles for medical disinfection applications. African Health Sciences. 19(1), 1441-1448.

Izadiyan, Z., Shameli, K., Hara, H., \& Mohd Taib, S.H. (2018) Cytotoxicity assay of biosynthesis gold nanoparticles mediated by walnut (Juglans regia) green husk extract. Journal of Molecular Structure. 1151, 97-105.

Kadiyala, N.K., Mandal, B.K., Ranjan, S., \& Dasgupta, N. (2018) Bioinspired gold nanoparticles decorated reduced graphene oxide nanocomposite using Syzygium cumini seed extract: Evaluation of its biological applications. Materials Science and Engineering C. 93, 191-205.

Kanchi, S., Kumar, G., Lo, A.Y., Tseng, C.M., Chen, S.K., Lin, C.Y., \& Chin, T.S. (2018) Exploitation of de-oiled jatropha waste for gold nanoparticles synthesis: A green approach. Arabian Journal of Chemistry. 11(2), 247-255.

Katas, H., Lim, C.S., Nor Azlan, A.Y.H., Buang, F., \& Mh Busra, M.F. (2019) Antibacterial activity of biosynthesized gold nanoparticles using biomolecules from Lignosus rhinocerotis and chitosan. Saudi Pharmaceutical Journal. 27(2), 283292.

Kaur, B., Malecka, K., Cristaldi, D.A., Chay, C.S., Mames, I., Radecka, H., Radecki, J., \& Stulz, E. (2018) Approaching single DNA molecule detection with an ultrasensitive electrochemical genosensor based on gold nanoparticles and cobalt-porphyrin DNA conjugates. Chemical Communications. 54(79), 11108-11111.

Karlík, M. 2001. Lattice Imaging in Transmission Electron Microscopy. Department of Materials, Faculty of Nuclea

Keshavamurthy, M., Srinath, B.S., \& Rai, V.R. (2018) Phytochemicals-mediated green synthesis of gold nanoparticles using Pterocarpus santalinus L. (Red Sanders) bark extract and their antimicrobial properties. Particulate Science and Technology. 36(7), 785-790.

Keshavarzi, M., Davoodi, D., Pourseyedi, S., \& Taghizadeh, S. (2018) The effects of three types of alfalfa plants (Medicago sativa) on the biosynthesis of gold nanoparticles: an insight into phytomining. Gold Bulletin. 51(3), 99-110.

Khairurrijal dan Mikrajuddin. 2009. Membangun 
Kemampuan Riset Nanomaterial di Indonesia. Bandung : ITB

Khandanlou, R., Murthy, V., Saranath, D., \& Damani, H. (2018) Synthesis and characterization of goldconjugated Backhousia citriodora nanoparticles and their anticancer activity against MCF-7 breast and HepG2 liver cancer cell lines. Journal of Materials Science. 53(5), 3106-3118.

Khoshnamvand, M., Ashtiani, S., Huo, C., Saeb, S.P., \& Liu, J. (2019) Use of Alcea rosea leaf extract for biomimetic synthesis of gold nanoparticles with innate free radical scavenging and catalytic activities. Journal of Molecular Structure. 1179, 749-755.

Kimling, J., Maier, M., Okenve, B., Kotaidis, V., Ballot, H., \& Plech, A. (2006) Turkevich method for gold nanoparticle synthesis revisited. Journal of Physical Chemistry B. 110(32), 15700-15707.

Kumar, P. Saravana, Jeyalatha, M.V., Malathi, J., \& Ignacimuthu, S. (2018) Anticancer effects of one-pot synthesized biogenic gold nanoparticles (McAuNps) against laryngeal carcinoma. Journal of Drug Delivery Science and Technology. 44, 118128.

Kumar, I., Mondal, M., Meyappan, V., \& Sakthivel, N. (2019) Green one-pot synthesis of gold nanoparticles using Sansevieria roxburghiana leaf extract for the catalytic degradation of toxic organic pollutants. Materials Research Bulletin. 117(April), 18-27.

Kutchko, B.G. \& Kim, A.G. (2006) Fly ash characterization by SEM-EDS. Fuel. 85(17-18), 2537-2544.

Liu, B., Lu, L., Hua, E., Jiang, S., \& Xie, G. (2012) Detection of the human prostate-specific antigen using an aptasensor with gold nanoparticles encapsulated by graphitized mesoporous carbon. Microchimica Acta. 178(1-2), 163-170.

Li, S. \& Drago, G.A. (2016) Bioconjugation and stabilisation of biomolecules in biosensors. . (June), 59-68.

Lim, S.H. \& Park, Y. (2017) Green Synthesis, Characterization and Catalytic Activity of Gold Nanoparticles Prepared Using Rosmarinic Acid. Journal of Nanoscience and Nanotechnology. 18(1), 659-667.

Mariychuk, R., Fejer, J., Porubska, J., Grishchenko, L.M., \& Lisnyak, V. V. (2019) Green synthesis and characterization of gold triangular nanoprisms using extract of Juniperus communis L. Applied Nanoscience. 0(0), 0.

Liu, B. \& Liu, J. (2019) Interface-Driven Hybrid Materials Based on DNA-Functionalized Gold Nanoparticles. Matter. 1(4), 825-847.

Miri, A., Darroudi, M., Entezari, R., \& Sarani, M. (2018) Biosynthesis of gold nanoparticles using Prosopis farcta extract and its in vitro toxicity on colon cancer cells. Research on Chemical
Intermediates. 44(5), 3169-3177.

Mirau, P.A., Smith, J.E., Chávez, J.L., Hagen, A., Kelley-loughnane, N., \& Naik, R.R. (2017) Structured DNA Aptamer Interactions with Gold Nanoparticles.

Mirkin, C.A., Letsinger, R.L., Mucic, R.C. and Storhoff, J.J., 1996. A DNA-based method for rationally assembling nanoparticles into macroscopic materials. Nature, 382(6592), p.607.

Mohd Taib, S.H., Shameli, K., Moozarm Nia, P., Etesami, M., Miyake, M., Rasit Ali, R., AbouzariLotf, E., \& Izadiyan, Z. (2019) Electrooxidation of nitrite based on green synthesis of gold nanoparticles using Hibiscus sabdariffa leaves. Journal of the Taiwan Institute of Chemical Engineers. 95, 616626.

Mythili, R., Selvankumar, T., Srinivasan, P., Sengottaiyan, A., Sabastinraj, J., Ameen, F., AlSabri, A., Kamala-Kannan, S., Govarthanan, M., \& Kim, H. (2018) Biogenic synthesis, characterization and antibacterial activity of gold nanoparticles synthesised from vegetable waste. Journal of Molecular Liquids. 262, 318-321.

Naimi-Shamel, N., Pourali, P., \& Dolatabadi, S. (2019) Green synthesis of gold nanoparticles using Fusarium oxysporum and antibacterial activity of its tetracycline conjugant. Journal de Mycologie Medicale. 29(1), 7-13.

Nagalingam, M., V. N., K., V., D.R., \& Panneerselvam, A. (2018) Biosynthesis, characterization, and evaluation of bioactivities of leaf extract-mediated biocompatible gold nanoparticles from Alternanthera bettzickiana. Biotechnology Reports. 19.

Nguyen, T.T.N., Vo, T.T., Nguyen, B.N.H., Nguyen, D.T., Dang, V.S., Dang, C.H., \& Nguyen, T.D. (2018) Silver and gold nanoparticles biosynthesized by aqueous extract of burdock root, Arctium lappa as antimicrobial agent and catalyst for degradation of pollutants. Environmental Science and Pollution Research. 25(34), 34247-34261.

Nishanthi, R., Malathi, S., S., J.P., \& Palani, P. (2019) Green synthesis and characterization of bioinspired silver, gold and platinum nanoparticles and evaluation of their synergistic antibacterial activity after combining with different classes of antibiotics. Materials Science and Engineering C. 96, 693-707.

Niu, J., Liu, Y., Wang, W., \& Lin, W. (2019) A novel mitochondria-targetable probe for imaging endogenous deoxyribonucleic acid in biological systems. Journal of Photochemistry and Photobiology A: Chemistry. 378(April), 57-65.

Ouano, J.J.S., Que, M.C.O., Basilia, B.A., \& Alguno, A.C. (2018) Controlling the absorption spectra of gold nanoparticles synthesized via green synthesis using brown seaweed (Sargassum crassifolium) 
extract. In Key Engineering Materials. Trans Tech Publications Ltd, pp. 78-82.

Ovais, M., Khalil, A.T., Raza, A., Islam, N.U., Ayaz, M., Saravanan, M., Ali, M., Ahmad, I., by Dove Press, published (2018) IJN-157958-greensynthesis-of-gold-and-silver-nanoparticles-fromcannab.

Shahid, M., \& Shinwari, Z.K. (2018) Multifunctional theranostic applications of biocompatible greensynthesized colloidal nanoparticles. Applied Microbiology and Biotechnology. 102(10), 4393 4408.

Oyar, P., Sana, F.A., Nasseri, B., \& Durkan, R. (2018) Effect of green gold nanoparticles synthesized with plant on the flexural strength of heat-polymerized acrylic resin. Nigerian Journal of Clinical Practice. 21(10), 1291-1295.

Patil, M.P., Bayaraa, E., Subedi, P., Piad, L.L.A., Tarte, N.H., \& Kim, G. Do (2019) Biogenic synthesis, characterization of gold nanoparticles using Lonicera japonica and their anticancer activity on HeLa cells. Journal of Drug Delivery Science and Technology. 51(December 2018), 83-90.

Patil, M.P., Seo, Y.B., Lim, H.K., \& Kim, G. Do (2019) Biofabrication of gold nanoparticles using Agrimonia pilosa extract and their antioxidant and cytotoxic activity. Green Chemistry Letters and Reviews. 12(3), 208-216.

Pingarrón, J.M., Yáñez-Sedeño, P., \& GonzálezCortés, A. (2008) Gold nanoparticle-based electrochemical biosensors. Electrochimica Acta. 53(19), 5848-5866.

Poturnayová, A., Dzubinová, L., Buríková, M., Bízik, J., \& Hianik, T. (2019) Detection of Breast Cancer Cells Using Acoustics Aptasensor Specific to HER2 Receptors. Biosensors. 9(2), 1-15.

Princy, K.F. \& Gopinath, · Anu (2018) Optimization of physicochemical parameters in the biofabrication of gold nanoparticles using marine macroalgae Padina tetrastromatica and its catalytic efficacy in the degradation of organic dyes. Journal of Nanostructure in Chemistry. 8, 333-342.

Qian, L., Su, W., Wang, Y., Dang, M., Zhang, W., \& Wang, C. (2019) Synthesis and characterization of gold nanoparticles from aqueous leaf extract of Alternanthera sessilis and its anticancer activity on cervical cancer cells (HeLa). Artificial Cells, Nanomedicine and Biotechnology. 47(1), 11731180.

Rashid, J.I.A. \& Yusof, N.A. (2017) The strategies of DNA immobilization and hybridization detection mechanism in the construction of electrochemical DNA sensor: A review. Sensing and Bio-Sensing Research. 16, 19-31.

Reetz, M.T., Helbig, W., Quaiser, S.A., Stimming, U., Breuer, N., \& Vogel, R. (1995) Visualization of surfactants on nanostructured palladium clusters by a combination of STM and high-resolution TEM. Science. 267(5196), 367-369.

Reetz, M.T. \& Helbig, W. (1994) Size-Selective Synthesis of Nanostructured Transition Metal Clusters. Journal of the American Chemical Society. 116(16), 7401-7402

Shamprasad, B.R., Keerthana, S., Megarajan, S., Lotha, R., Aravind, S., \& Veerappan, A. (2019) Photosynthesized escin stabilized gold nanoparticles exhibit antidiabetic activity in L6 rat skeletal muscle cells. Materials Letters. 241, 198-201.

Rohiman, A., Buchari, Amran, B.., Juliastuti, E., \& Idris, I. (2014) Sintesis, Karakterisasi, dan Aplikasi Gold Nanoparticle (AuNPs) pada Penumbuhan Silicon Nanowires. Research and Development on Nanotechnology in Indonesia. 1(2), 74-82.

Shon, Y.-S., Chuc, S., \& Voundi, P. (2009). Stability of tetraoctylammonium bromide-protected gold nanoparticles: Effects of anion treatments. Colloids and Surfaces A: Physicochemical and Engineering Aspects, 352(1-3), 12-17.

Singh, A.K., Tiwari, R., Singh, V.K., Singh, P., Khadim, S.R., Singh, U., Laxmi, Srivastava, V., Hasan, S.H., \& Asthana, R.K. (2019) Green synthesis of gold nanoparticles from Dunaliella salina, its characterization and in vitro anticancer activity on breast cancer cell line. Journal of Drug Delivery Science and Technology. 51(February), 164-176.

Sovawi, A.C. \& Kimia, J. (2016) Info Artikel. . 5(3).

Sunderam, V., Thiyagarajan, D., Lawrence, A.V., Mohammed, S.S., \& Selvaraj, A. (2018) In-vitro antimicrobial and anticancer properties of green synthesized gold nanoparticles using Anacardium occidentale leaves extract. Saudi Journal of Biological Sciences.

Szcs, R., Balogh-Weiser, D., Sánta-Bell, E., TóthSzeles, E., Varga, T., Kónya, Z., Poppe, L., \& Lagzi, I. (2019) Green synthesis and: In situ immobilization of gold nanoparticles and their application for the reduction of $\mathrm{p}$-nitrophenol in continuous-flow mode. RSC Advances. 9(16), 9193-9197.

Sutter, E., Zhang, B., Sutter, S., \& Sutter, P. (2019) In situ electron microscopy of the self-assembly of single-stranded DNA-functionalized Au nanoparticles in aqueous solution. Nanoscale. 11(1), 34-44.

Thakkar, K. N., Mhatre, S. S., \& Parikh, R. Y. 2010. Biological Synthesis of Metallic Nanoparticles. Nanomedicine: Nanotechnology, Biology, and Medicine, 6(2), 257-262.

Torabi, S. \& Lu, Y. (2014) ScienceDirect Functional DNA nanomaterials for sensing and imaging in living cells. , 88-95.

Turkevich, J., Stevenson, P.C., \& Hillier, J. (1951) A 
study of the nucleation and growth processes in the synthesis of colloidal gold. Discussions of the Faraday Society. 11(c), 55-75.

Umamaheswari, C., Lakshmanan, A., \& Nagarajan, N.S. (2018) Green synthesis, characterization and catalytic degradation studies of gold nanoparticles against congo red and methyl orange. Journal of Photochemistry and Photobiology B: Biology. 178, 33-39.

Usman, A.I., Aziz, A.A., \& Noqta, O.A. (2018) Biosynthesis of triangular and hexagonal gold nanoparticles using palm oil fronds' extracts at room temperature. Materials Research Express. 5(1).

Usman, A.I., Aziz, A.A., \& Noqta, O.A. (2019) Green sonochemical synthesis of gold nanoparticles using palm oil leaves extracts. Materials Today: Proceedings. 7, 803-807.

Veena, S., Devasena, T., Sathak, S.S.M., Yasasve, M., \& Vishal, L.A. (2019) Green Synthesis of Gold Nanoparticles from Vitex negundo Leaf Extract: Characterization and In Vitro Evaluation of Antioxidant-Antibacterial Activity. Journal of Cluster Science. 30(6), 1591-1597.

Vijayan, R., Joseph, S., \& Mathew, B. (2018) Ecofriendly synthesis of silver and gold nanoparticles with enhanced antimicrobial, antioxidant, and catalytic activities. IET Nanobiotechnology. 12(6), 850-856.

Vijayan, R., Joseph, S., \& Mathew, B. (2018) Ecofriendly synthesis of silver and gold nanoparticles with enhanced antimicrobial, antioxidant, and catalytic activities. IET Nanobiotechnology. 12(6), $850-856$.

Vijaya Kumar, P., Mary Jelastin Kala, S., \& Prakash, K.S. (2019) Green synthesis of gold nanoparticles using Croton Caudatus Geisel leaf extract and their biological studies. Materials Letters. 236, 19-22.

Vimalraj, S., Ashokkumar, T., \& Saravanan, S. (2018) Biogenic gold nanoparticles synthesis mediated by Mangifera indica seed aqueous extracts exhibits antibacterial, anticancer and anti-angiogenic properties. Biomedicine and Pharmacotherapy. 105, 440-448.

Vijaya Kumar, P., Mary Jelastin Kala, S., \& Prakash, K.S. (2019) Green synthesis of gold nanoparticles using Croton Caudatus Geisel leaf extract and their biological studies. Materials Letters. 236, 19-22.
Vijayan, R., Joseph, S., \& Mathew, B. (2019) Anticancer, antimicrobial, antioxidant, and catalytic activities of green-synthesized silver and gold nanoparticles using Bauhinia purpurea leaf extract. Bioprocess and Biosystems Engineering . 42(2), 305319.

Wang, L., Xu, J., Yan, Y., Liu, H., Karunakaran, T., \& Li, F. (2019) Green synthesis of gold nanoparticles from Scutellaria barbata and its anticancer activity in pancreatic cancer cell (PANC-1). Artificial Cells, Nanomedicine and Biotechnology. 47(1), 16171627.

Wang, Chung-Yu dan Li-Wei Wu. 2011. Reference Effects on Revisit Intentio Involvement As A Moderator. Taylor \& Francis Group, LLC.

Wang, C.C., Wu, S.M., Li, H.W., \& Chang, H.T. (2016) Biomedical Applications of DNAConjugated Gold Nanoparticles. ChemBioChem, 1052-1062.

Wacławek, S., Gončuková, Z., Adach, K., Fijałkowski, M., \& Černík, M. (2018) Green synthesis of gold nanoparticles using Artemisia dracunculus extract: control of the shape and size by varying synthesis conditions. Environmental Science and Pollution Research. 25(24), 24210-24219.

Yang, B., Qi, F., Tan, J., Yu, T., \& Qu, C. (2019) Study of green synthesis of ultrasmall gold nanoparticles using citrus sinensis peel. Applied Sciences (Switzerland). 9(12).

Zayadi, R.A., Abu Bakar, F., \& Ahmad, M.K. (2019) Elucidation of synergistic effect of eucalyptus globulus honey and Zingiber officinale in the synthesis of colloidal biogenic gold nanoparticles with antioxidant and catalytic properties. Sustainable Chemistry and Pharmacy. 13(March), 100156.

Zeng, S., Yong, K., \& Roy, I. (2011) A Review on Functionalized Gold Nanoparticles for Biosensing Applications. , 491-506.

Zhang, Y. Zhang, X. Wang, Z.M. Tang, Z.H. Lu, Hyper-Rayleigh scattering

of protein-modified gold nanoparticles, Anal. Biochem. 320 (2003) 136e140.

Zhao, S., Chen, D., Geng, Q., \& Wang, Z. (2013) The highly conserved LAMMER / CLK2 protein kinases prevent germ cell overproliferation in Drosophila. Developmental Biology. 376(2), 163-170.

Zhao, Y. \& Xie, X. (2018) Yanling Zhao and Xianmei Xie. 29(2), 232-239. 